\title{
LOGGING IMPACTS IN TROPICAL LOWLAND HUMID FOREST ON TREE SPECIES DIVERSITY AND ENVIRONMENTAL CONSERVATION
}

\author{
AdEKUNLE, V.A.J. ${ }^{1}{ }^{1}-$ OLAGOKE, A.O. ${ }^{1}-$ OGUNDARE, L.F. ${ }^{2}$ \\ ${ }^{I}$ Federal University of Technology, Department of Forestry and Wood Technology Akure, \\ Nigeria \\ ${ }^{2}$ Ondo State Ministry of Agriculture, Forestry and Fisheries, Forestry and Wildlife Services, \\ Akure, Nigeria \\ *Corresponding author \\ e-mail:vajadekunle@yahoo.com \\ (Received $2^{\text {nd }}$ February 2008; accepted $5^{\text {th }}$ September 2013)
}

\begin{abstract}
This study assessed the effects of exploitations in natural forest ecosystem on tree species diversity and environmental conservation. This was achieved by comparing tree species diversity and yield in an unlogged forest (inviolate/strict nature reserve) and part of the forest reserve where active logging is in progress. Both forest types are located in Akure Forest reserve, Ondo State, Nigeria. Eight plots $(20 \times 20 \mathrm{~m})$ were located in each site using systematic sampling technique. All living trees with dbh $>10 \mathrm{~cm}$ were identified in each plot and categorized into families. Ddiameter at breast height was measured from each of the trees in each plot. This was used to compute basal area and volume. Relative frequency, relative density and habitat occupancy were obtained and compared. Shannon-Weiner and species evenness indices were used to assess and compare tree species diversity and abundance. The result shows that the tropical humid forest is very rich in tree species diversity as a total of 54 different tropical hardwood species from 24 families were encountered in both forest types. There are 46 species distributed among 21 families in the inviolate forest while 24 species in 14 families were in the logged forest. Higher values of Shannon-Weiner (3.16 and 3.03 for inviolate and logged respectively) and evenness index ( 0.83 and 0.81$)$ are also obtained for the inviolate and logged forest respectively. The stand density in the inviolate is $555 \mathrm{stems} / \mathrm{ha}$ and that of the logged forest is $132 \mathrm{stems} / \mathrm{ha}$. A mean dbh of $39.35 \mathrm{~cm}$ and $14.24 \mathrm{~cm}$, basal area of $10.34 \mathrm{~m}^{2} / \mathrm{ha}$ and $2.14 \mathrm{~m} / \mathrm{ha}$ and volume of $1235.04 \mathrm{~m}^{3}$ and 14.81 $\mathrm{m}^{3}$ were obtained for the inviolate and logged forests respectively. In the inviolate forest, the species with the highest number of occurrence is Mansonia altissima (80stems/ha) and Caesalpinoidae and Sterculiaceae families have the highest number of species (6). In the logged forest, Triplochiton scleroxylon (18 stems/ha) has the highest frequency and Caesalpinoidae family has the highest number of species (4). There are significant differences in all the variables estimated $(\mathrm{P}<0.5)$ with result from the inviolate forest having the highest value. The study concluded that exploitation has affected species diversity in the ecosystem and subsequently, the roles of trees in environmental conservation are affected. Keywords: Inviolate, Strict Nature Reserve, exploitation, deforestation, systematic sampling technique
\end{abstract}

\section{Introduction}

Due to population growth, exploitation of natural resources in the developing countries of the world is increasing at an alarming rate. The current rate of forest deforestation in the southwest geo-political zone of Nigeria was put at $1.36 \%$ per annum by Salami (2006) when he monitored Nigerian forest with Nigeriasat-1 and other satellites. He noted that this value falls within the global range of between 1.0 and $2.0 \%$ suggested by Reiss et al. (1980) and 1.0 and $1.5 \%$ by World Bank (1991) for developing countries of the world. But it is above the national deforestation rate $(0.76 \%)$ suggested for Nigeria by FAO (1990) and lower than the estimation (3.5\%) of 
the Federal Department of Forestry for the country. If something is not done to reduce this current exploitation rate urgently, it could lead to biodiversity loss and severe environmental condition.

Mabogunje (1988) identified three main forms of environmental stress the resilience and stability of forest ecosystem are been subjected to. The stresses are (i) exploitative stress arising from the direct rate at which plant and animal species are been wiped out to the extent that these species are threatened with extinction especially those with narrow range. (ii) disruptive stress which involves the modification of the structure by fire, overgrazing or over cropping to the point where the ecosystem is highly susceptible to invasion and replacement and (iii) eutrophic stress that is caused by the deposition of waste and food residues in small areas where concentration of nutrients can occur and affects plant growth and the balance of the ecosystem. All these forms of stressed are present in Nigerian forest ecosystem but the impacts of the disruptive stress are manifested in increasing and accelerating degradation and depletion of forest cover (Ikhuoria, 2006).

All level of forest biota are affected by logging including aboveground (trees and understorey layers) and belowground (soil microbiota and edaphic). The potential impact of logging in tropical rainforest ecosystem has direct environmental and biological consequences. Laurance (2001) noted that logging opens mature forest area for colonization. Also, new roads are constructed in the forest during logging (Wilkie et al., 2000). This has the potential of increasing spontaneous colonization of logged forest by agricultural colonist. The ability of vegetation to improve the stability of slopes (through modification of the internal fraction of soil and root reinforcement) and subsequently, prevention of natural disaster such as landslides, floods, droughts and sea level rise have been reported by Wu et al. (1979), Bibalani et al. (2006) and Bibalani and Majnounian (2007). Also, the environmental roles of forest ecosystem are reduced when trees are cut indiscriminately. These roles include erosion and leaching control, wind break, micro-climate creation, carbon sequestration, air purification and provision of shade during hot season. Worst of all is climate change and global warming as a result of interference on the ecosystem. There is now a scientific interest concerning the impacts of global warming on terrestrial ecosystem as reported by Walther et al. (2002), Ranasinghe and Abayasiri (2007) and Verchot (2007). Information on floral composition, diversity and volume yield are absolutely essential in understanding forest ecosystem dynamics and conservation (Pascal and Pelssier, 1996). He noted further that the information could be used as tool to estimate the level of adaptation to the environment and their ecological significance.

Biodiversity refers to the variability among living organisms from all sources including, among other things, terrestrial, marine and other aquatic ecosystems and the ecological complexes of which they are part (SCBD, 2001). This includes biodiversity within species, between species and of ecosystem. Biological diversity was defined by its components (i. e. landscapes, ecosystems, communities, species population, and genes) and attributes (i. e. structures, compositions and functions) by Putz et al. (2000) and Lynch et al. (2004). It deals with a range of organisms in an environment or with a range of organisms present in a given ecological community or system. It could be measured by the numbers and types of different species or by type of the genetic variations within and between species.

Environment is the totality of man's surroundings with physical, chemical, and biotic components, which are in dynamic state of inter play but which is bedeviled with many 
hazardous human activities like unguided forest exploitation resulting in environmental pollution and degradation (Adeola, 1996; Alfred, 2005). Though other forms of land use could contribute to environmental hazards but the main concern of this study is the way and manner timber harvesting affects biodiversity conservation and the environment. This study is therefore on the impacts of logging on tree species diversity, forest structure, composition and volume yield. The consequent impact on the environment is also assessed.

\section{Methodology}

\section{The Study Area}

The present Ondo State is one of the 36 states of Nigeria. The State is spread over a landed area of 14788,728 square kilometers and lies within longitudes $4^{0} 30^{1} \& 6^{0}$ East of the Greenwich meridian and latitudes $5^{0} 45^{1}$ and latitudes $8^{0} 15^{1}$ North of Equator and it is bounded in the South by the Atlantic Ocean. The climate is humid sub-tropical indicating that it is basically within the tropical rain forest zone dominated by broadleaved trees that form dense layered stands which usually are above 50m (165 ft) in height. The trees could be seen to be green throughout the year because they retain their leaves all through the year. This is because the temperature and precipitation are sufficiently high for continuous growth. It is an agrarian state and Salami (2006) referred to the state as the leading timber producing state in south-west Nigeria.

\section{Method of data collection}

\section{Sample Plots Demarcation}

Systematic sampling design (systematic line transect) was employed for the laying of plots. Field enumeration was carried out at Akure forest reserve. This reserve is one of the sixteen forest reserve in the Ondo State. Figure 1 is the map of Ondo state showin the locations of the different forest reserves and Akure forest reserve in inset. It was selected for this study because it has a portion under strict protection. This particular portion of the forest reserve was constituted as Strict Nature Reserve by the Forestry Research Institute of Nigeria and it is one of the six SNRs (SNR No. 1) in Nigeria (Adekunle, 2005). Strict Natural Reserves are created to protect representative samples of natural ecosystems for preservation of biodiversity and ecological processes, for scientific study, environmental monitoring, education and for the maintenance of genetic resources in a dynamic and evolutionary state (Isichei, 1995).

This SNR (also referred to as inviolate forest) and the adjacent forest area where active logging activities are in progress (violate forest) were selected for data collection. Since the SNR is under total protection, it provides a base line for measuring tree species diversity and loss in other part of the reserve where logging is taking place. Two transects with a distance of $500 \mathrm{~m}$ between them were laid at the centre of each of the two forest types. Sample plots of equal size $(20 \times 20 \mathrm{~m})$ were laid in alternate direction along each transect at $250 \mathrm{~m}$ interval and thus summing up to 4 sample plots per transect and a total of 8 sample plots per study site (Fig. 2). Using this method ensured that the forest is relatively covered. So a total of $1600 \mathrm{~m}^{2}$ were sampled in each forest type. 


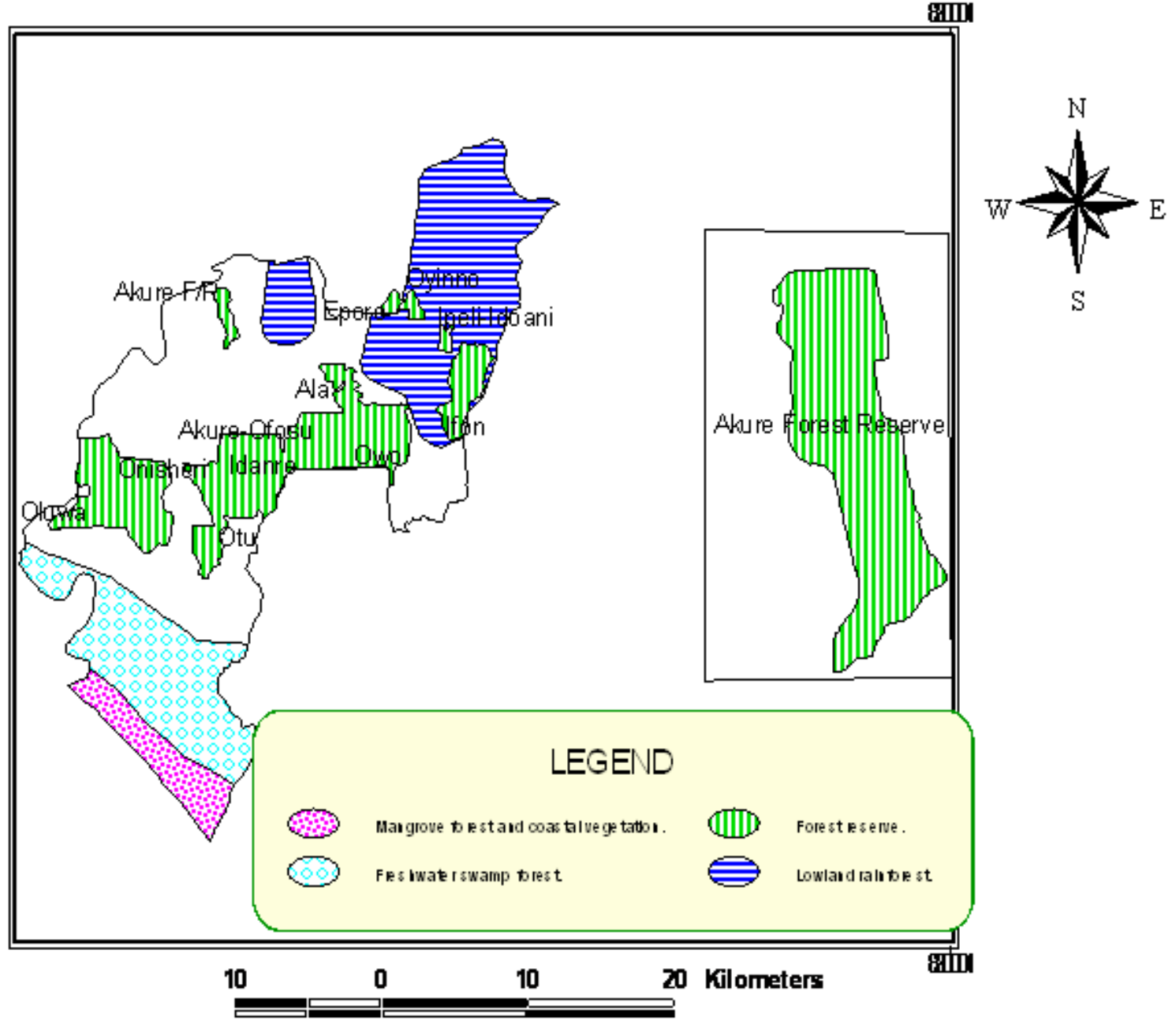

Figure 1. Map of Ondo State showing all existing forest reserves (Akure forest reserve in inset)

\section{Measurement of Tree Growth Variables in the Forest Reserves and Free Areas}

Measurement and identification of all woody plants with diameter at breast height of $10 \mathrm{~cm}$ and above were carried out. The tree growth variables measured include dbh and height.

\section{Tree Species Identification}

The botanical name of every living tree that was encountered in each sample plot was recorded for each of the study sites. Where a tree's botanical name was not known immediately, such a tree was identified by its commercial or local name. Such commercial or local names were translated to correct botanical names using Gbile (1984) and Keay (1989). Trees that could not be identified were tagged 'unknown'. Specimens of such unknown trees were collected and preserved and taken to Forestry Herbarium, Ibadan (FHI) of the Forestry Research Institute of Nigeria for their identification. Each tree species was recorded individually in the field forms and possible effort was made not to omit any eligible stem in a sample plot. This is because any species omitted will indicate the absence of such species in the ecosystem. 


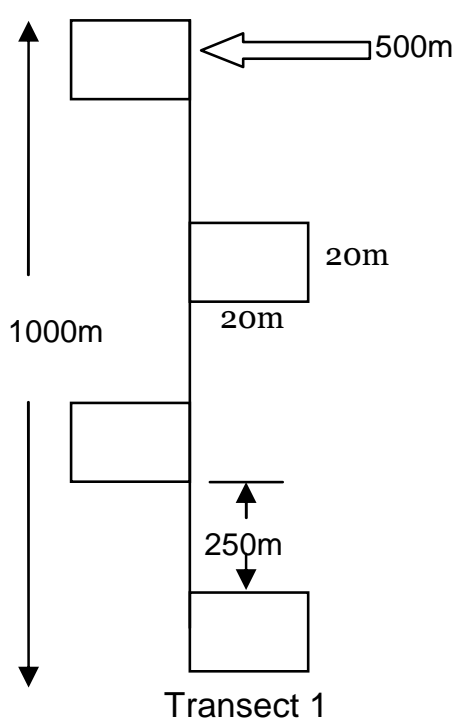

Figure 2. Plots location using systematic line transect

\section{Data Analysis}

\section{Basal Area Calculation}

The basal area of all trees in the sample plots was calculated using the formula:

$$
\mathrm{BA}=\frac{\pi \mathrm{D}^{2}}{4}
$$

Where $\mathrm{BA}=$ Basal area $\left(\mathrm{m}^{2}\right), \mathrm{D}=$ Diameter at breast height $(\mathrm{cm})$ and $\pi=$ Pie (3.142).

The total basal area for each of the sample plots was obtained by adding the BA of all trees in the plot while mean BA for the plot $\left(\overline{B A}_{p}\right)$ was obtained by dividing the total BA by the number of sample plots.

Basal area per hectare was obtained by multiplying mean basal per plot with the number of $20 \times 20 \mathrm{~m}$ plots in a hectare (25).

$$
\mathrm{BA}_{\mathrm{ha}}=\overline{\mathrm{BA}}_{\mathrm{P}} \times 25
$$

Where $B A_{h a}=$ basal area per hectare

\section{Volume Calculation}

The volume of individual trees was estimated using the equation developed for tree volume estimation in lowland rainforest ecosystem of south-west Nigeria by FORMECU (1999). This equation is expressed as follows:

$$
\mathrm{V}=\mathrm{e}^{-8.433+2.331 \operatorname{Ln}(\mathrm{D})}
$$


Where $\mathrm{V}=$ Volume of tree $\left(\mathrm{m}^{3}\right)$ and $\mathrm{D}=\mathrm{dbh}(\mathrm{cm})$.

Total plot volume was obtained by adding the volume of individual trees encountered in the plots. Mean volume for sample plots was calculated by dividing the total plot by the number of sample plots.

Volume per hectare was obtained by multiplying mean volume per plot $\bar{V}_{P}$ with the number of $20 \times 20 \mathrm{~m}$ plots in a hectare (25).

$$
\mathrm{V}_{\mathrm{ha}}=\overline{\mathrm{V}}_{\mathrm{P}} \times 25
$$

\section{Tree Species Classification and Diversity Indices}

All the trees encountered were assigned to families and number of species in each family was obtained for tree species diversity classification. Frequency of occurrence was obtained for species abundance/ richness. This was repeated for all plants encountered in the sample plots for the two sites. The following biodiversity indices were used to obtain tree species richness and evenness within each of the forest. They were also used as indices for comparing biodiversity as indication of biodiversity loss.

I. Species relative density (RD) was obtained using the formula given by Oduwaiye et al (2002):

$$
\mathrm{RD}=\left[\frac{\mathrm{n}_{\mathrm{i}}}{\mathrm{N}}\right] \times 100
$$

Where RD = relative density, $\mathrm{n}_{\mathrm{i}}=$ number of individuals of species $\mathrm{i}$ and $\mathrm{N}=$ total number of individuals in the entire population.

II. Relative dominance was obtained using the formula given by Brashears et.al (2004):

$$
\mathrm{RDo}=\frac{\left(\sum \mathrm{BA}_{\mathrm{i}} \times 100 .\right)}{\sum \mathrm{BA}_{\mathrm{n}}}
$$

Where $R D o=$ relative dominance, $\mathrm{BA}_{\mathrm{i}}=$ basal area of all individual trees belonging to a particular species $\mathrm{i}$ and $\mathrm{BA}_{\mathrm{n}}=$ stand basal area.

III. Relative Frequency (RF) was obtained using the formula given by Oduwaiye et al (2002):

$$
\mathrm{RF}=\frac{\sum \mathrm{F}_{\mathrm{i}} \times 100}{\mathrm{~F}_{\mathrm{n}}}
$$

Where $F_{i}=$ number of plots where species $i$ was found and $F_{n}=$ total frequency of all species.

IV. Community diversity was obtained using a mathematical formula that takes into account the species richness and abundance of each species in the ecological community. The equation for the Shannon-Wiener diversity index given by Price (1997) that was used is:

$$
\mathrm{H}^{1}=\sum_{\mathrm{i}=1}^{\mathrm{S}} \mathrm{p}_{\mathrm{i}} \operatorname{Lnp}_{\mathrm{i}}
$$


$\mathrm{H}^{1}$ is the Shannon diversity index, $\mathrm{S}$ is the total number of species in the community, $\mathrm{p}_{\mathrm{i}}$ is the proportion of a species to the total number of plants in the community and Ln is the natural logarithm.

V. Species evenness (E) in each community was determined using Shannon's equitability $\left(\mathrm{E}_{\mathrm{H}}\right)$ as stated by Kent and Coker (1992):

$$
\mathrm{E}=\frac{\mathrm{H}^{1}}{\operatorname{Ln}(\mathrm{S})}
$$

$\mathrm{S}$ is the total number of species in each community.

\section{Statistical Analysis}

Descriptive statistic was used to obtained mean values and the corresponding standard error. Spearman correlation coefficient was carried on some of the tree growth variable obtained in each of the sites while the student t-test were used to test for the presence of significant difference in tree species diversity indices and tree growth variables. All statistical analyses were carried out using SPSS version 14.

\section{Results}

The results of this study reveal that tropical forest ecosystem is very rich in timber hardwood species of relative importance.

\section{Tree Species diversity, structure and yield in the inviolate forest}

In the SNR, 46 tropical hardwood species distributed among 21 families was encountered. The Shannon-Weiner diversity index $\left(\mathrm{H}^{1}\right)$ was 3.16 and species evenness (E) was 0.83 . Tree density obtained is 549 stems/ha. The species abundance/frequencies ranged from 80stems/ha for Mansonia altissima which is the most occurrence species to only two for six species namely Blighia sapida, Borassus aethiopicum, Distemonanthus spp, Drypetes spp, Lonchocarpus sericeus and Phyllanthus discoideus. Thus, Mansonia altissima ( $80 \mathrm{stems} / \mathrm{ha}$ ) was the most abundant timber species, followed by Triplochiton scleroxylon (70), Celtis spp (68), then Sterculia oblonga (37), Sterculia rhinopetala (34), Cleistopholis patens (22) and Cola gigantea (20). Other species had below 20 stems/ha. The correlation between abundance and frequency was 0.92 and the coefficient of the relationship between abundance and dominance was 0.75 .

Of the total 21 families in this SNR, Caesalpinoidae and Sterculiaceae have the highest number of species, each with six species. This is followed by Meliaceae and Moraceae, each with five species. Thirteen families, accounting for about $61.90 \%$, were represented by only one species, only Combretaceae was represented by two species while each of the rest families, Euphorbiaceae, Papilionoidae and Rubiaceae has three species. Representative of Bombacaceae, Irvngiaceae and Myristicaceae which were encountered in the logged over forest were not found in the inviolate forest. Table 1 has the detail result of tree species diversity, relative abundance, volume/ha, relative frequency $(\mathrm{RF})$, relative density (RD), relative dominance (RDO) and Shannon-Weiner biodiversity index values obtained for the SNR.

The distribution of number of stem/ha and basal area/ha into dbh size classes for the inviolate site is presented in Figure 3. The number of individual tree species in the 
different diameter size classes revealed that the inviolate forest has the typical inverted $\mathrm{J}$ - shape curve expected of tropical natural forest yet to witness human interference. Except for only one tree that had a dbh of $210 \mathrm{~cm}$, the number of individual trees in each diameter size class dwindled from the lowest class $(10-20 \mathrm{~cm})$ to highest class $(>100$ $\mathrm{cm})$. While $29 \%$ belong to the lowest dbh class, $5 \%$ are in the highest class. Contrariwise, an increase in basal area was obtained with increase in diameter classes. Dominant tree with $210 \mathrm{~cm}$ dbh and mean dbh of $39.35 \pm 3.14 \mathrm{~cm}$ were also obtained for this site (Table 1).

Highest basal area $\left(26.78 \mathrm{~m}^{2} / \mathrm{ha}\right)$ was recorded for Triplochiton scleroxylon species only while the least $\left(0.04 \mathrm{~m}^{2} / \mathrm{ha}\right)$ was recorded for Drypetes paxii. About $58.70 \%$ of the total number of species had their basal area below $1.00 \mathrm{~m}^{2} /$ ha. Volume/ha for the timber species encountered followed the same pattern with that of basal area/ha. While the total basal area/ha is $105.34 \pm 12.02 \mathrm{~m}^{2}$, the total volume/ha is $1235.04 \pm 140.94 \mathrm{~m}^{3}$. There was a strong relationship with a correlation coefficient of 0.994 between basal area/ha and volume/ha (Table 2). 
Table 1. Timber Resources Diversity, Abundance, BA/ha, Vol/ha, RF, RD, RDO and Shannon-Weiner Diversity Index for the SNR, Akure Forest Reserve

\begin{tabular}{|c|c|c|c|c|c|c|c|c|c|c|}
\hline \multirow{29}{*}{ 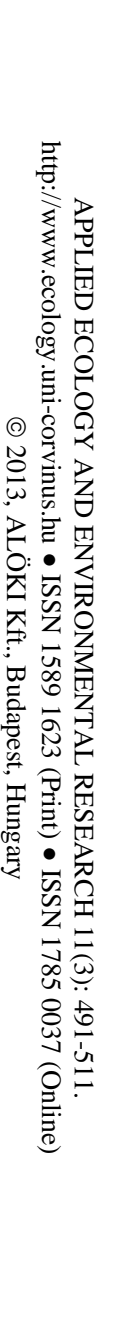 } & $\mathbf{s} / \mathbf{n}$ & Tree species & Family & Abundance/ha & BA/ha $\left(\mathbf{m}^{2}\right)$ & Vol/ha $\left(\mathrm{m}^{3}\right)$ & $\mathbf{R F}$ & RD & RDO & piLnpi \\
\hline & 1 & Afromosia elata & Papilionoidae & 5 & 1.5240 & 18.1770 & 1.6129 & 0.9107 & 1.4627 & -0.0430 \\
\hline & 2 & Afzelia africana & Caesalpinoidae & 7 & 0.7569 & 7.0436 & 2.4194 & 1.2750 & 0.7265 & -0.0560 \\
\hline & 3 & Antiaris africana & Moraceae & 7 & 0.8979 & 9.0066 & 0.8065 & 1.2750 & 0.8618 & -0.0560 \\
\hline & 4 & Berlinia confusa & Caesalpinoidae & 5 & 0.2562 & 2.1329 & 0.8065 & 0.9107 & 0.2459 & -0.0430 \\
\hline & 5 & Blighia sapida & Sapindaceae & 2 & 0.0762 & 0.5662 & 0.8065 & 0.3643 & 0.0731 & -0.0205 \\
\hline & 6 & Borassus aethiopicum & Moraceae & 2 & 0.0809 & 0.6072 & 0.8065 & 0.3643 & 0.0776 & -0.0205 \\
\hline & 7 & Bosqueia angolensis & Moraceae & 3 & 0.0770 & 0.5729 & 0.8065 & 0.5464 & 0.0739 & -0.0285 \\
\hline & 8 & Brachystegia eurycoma & Caesalpinoidae & 5 & 0.2297 & 1.8693 & 1.6129 & 0.9107 & 0.2205 & -0.0430 \\
\hline & 9 & Carapa procera & Meliaceae & 5 & 0.1752 & 1.3547 & 1.6129 & 0.9107 & 0.1682 & -0.0430 \\
\hline & 10 & Celtis zenkeri & Ulmaceae & 68 & 8.7726 & 97.2840 & 7.2581 & 12.3862 & 8.4197 & -0.2590 \\
\hline & 11 & Chrysophyllum spp & Sapotaceae & 12 & 1.2177 & 11.1480 & 3.2258 & 2.1858 & 1.1687 & -0.0836 \\
\hline & 12 & Cleistopholis patens & Annonaceae & 22 & 1.3329 & 11.4510 & 3.2258 & 4.0073 & 1.2793 & -0.1300 \\
\hline & 13 & Cola gigantea & Sterculiaceae & 20 & 12.9670 & 191.7100 & 4.8387 & 3.6430 & 12.4454 & -0.1210 \\
\hline & 14 & Combretodendron spp & Lecythidaceae & 10 & 0.6849 & 6.1926 & 2.4194 & 1.8215 & 0.6573 & -0.0730 \\
\hline & 15 & Cordia millenii & Boraginaceae & 12 & 4.1388 & 47.6460 & 2.4194 & 2.1858 & 3.9723 & -0.0836 \\
\hline & 16 & Daniellia ogea & Caesalpinoidae & 3 & 0.9134 & 10.2350 & 0.8065 & 0.5464 & 0.8767 & -0.0285 \\
\hline & 17 & Diospyros & Ebenaceae & 5 & 0.0853 & 0.5893 & 0.8065 & 0.9107 & 0.0819 & -0.0430 \\
\hline & 18 & Distemonanthus & Caesalpinoidae & 2 & 0.0454 & 0.3093 & 0.8065 & 0.3643 & 0.0436 & -0.0205 \\
\hline & 19 & Drypetes paxii & Euphorbiaceae & 2 & 0.0402 & 0.2683 & 0.8065 & 0.3643 & 0.0386 & -0.0205 \\
\hline & 20 & $\begin{array}{l}\text { Entandrophragma } \\
\text { cylindricum }\end{array}$ & Meliaceae & 3 & 0.2139 & 1.8845 & 0.8065 & 0.5464 & 0.2053 & -0.0285 \\
\hline & 21 & Entandrophragma utile & Meliaceae & 3 & 0.8606 & 9.5489 & 0.8065 & 0.5464 & 0.8260 & -0.0285 \\
\hline & 22 & Erythrophilleum spp & Caesalpinoidae & 5 & 0.3129 & 2.6383 & 0.8065 & 0.9107 & 0.3003 & -0.0428 \\
\hline & 23 & Fagara spp & Rutaceae & 3 & 0.2297 & 2.0481 & 0.8065 & 0.5464 & 0.2205 & -0.0285 \\
\hline & 24 & Ficus spp & Moraceae & 10 & 2.6514 & 30.5150 & 2.4194 & 1.8215 & 2.5447 & -0.0730 \\
\hline & 25 & Funtumia elastica & Apocynaceae & 12 & 0.4426 & 3.5775 & 4.0323 & 2.1858 & 0.4248 & -0.0836 \\
\hline & 26 & Hannoa klaineana & Simaroubaceae & 3 & 1.1947 & 13.9961 & 0.8065 & 0.5464 & 1.1466 & -0.0285 \\
\hline & 27 & Khaya spp & Meliaceae & 3 & 0.0515 & 0.3589 & 0.8065 & 0.5464 & 0.0494 & -0.0285 \\
\hline & 28 & Lannea welwitschii & Anacardiaceae & 5 & 1.8639 & 22.8640 & 1.6129 & 0.9107 & 1.7889 & -0.0430 \\
\hline
\end{tabular}




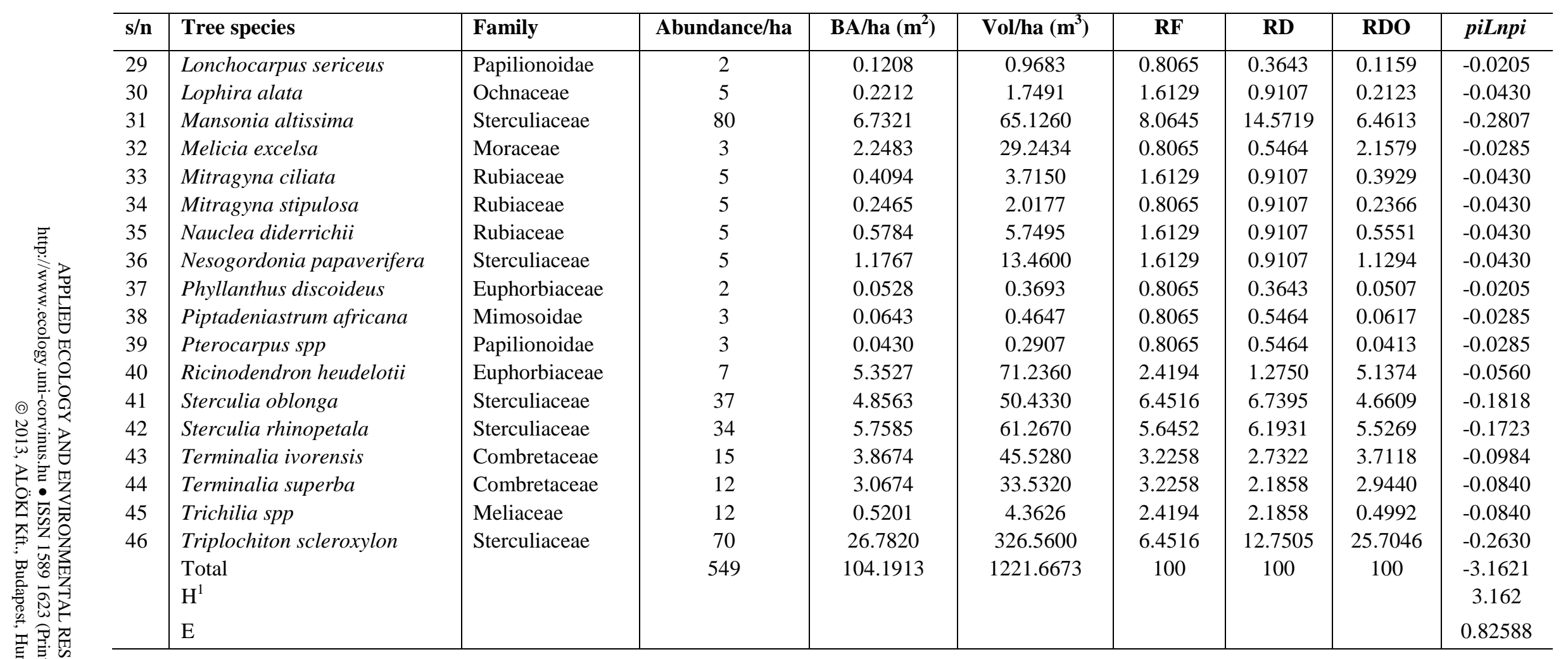

Table 2. Correlation matrix for the Inviolate forest site

\begin{tabular}{l|l|l|l|l|l|l}
\hline & \multicolumn{1}{|c|}{ Abundance/ha } & BA/ha (m2) & Vol/ha (m3) & \multicolumn{1}{|c|}{ RF } & \multicolumn{1}{|c}{ RD } & RDO \\
\hline Abundance/ha & 1 & & & & & \\
BA/ha (m2) & 0.746823 & 1 & & & & \\
Vol/ha (m3) & 0.688835 & 0.994136 & 1 & & & \\
RF & 0.921181 & 0.697238 & 0.653066 & 1 & & \\
RD & 1 & 0.746823 & 0.688835 & 0.921181 & 1 & \\
RDO & 0.746823 & 1 & 0.994136 & 0.697238 & 0.746823 & 1 \\
\hline
\end{tabular}


Table 3. Timber Resources Diversity, Family, Abundance, BA/ha, Vol/ha, RF, RD, RDO and Shannon-Weiner Diversity Index of the violate Area in Akure forest reserve

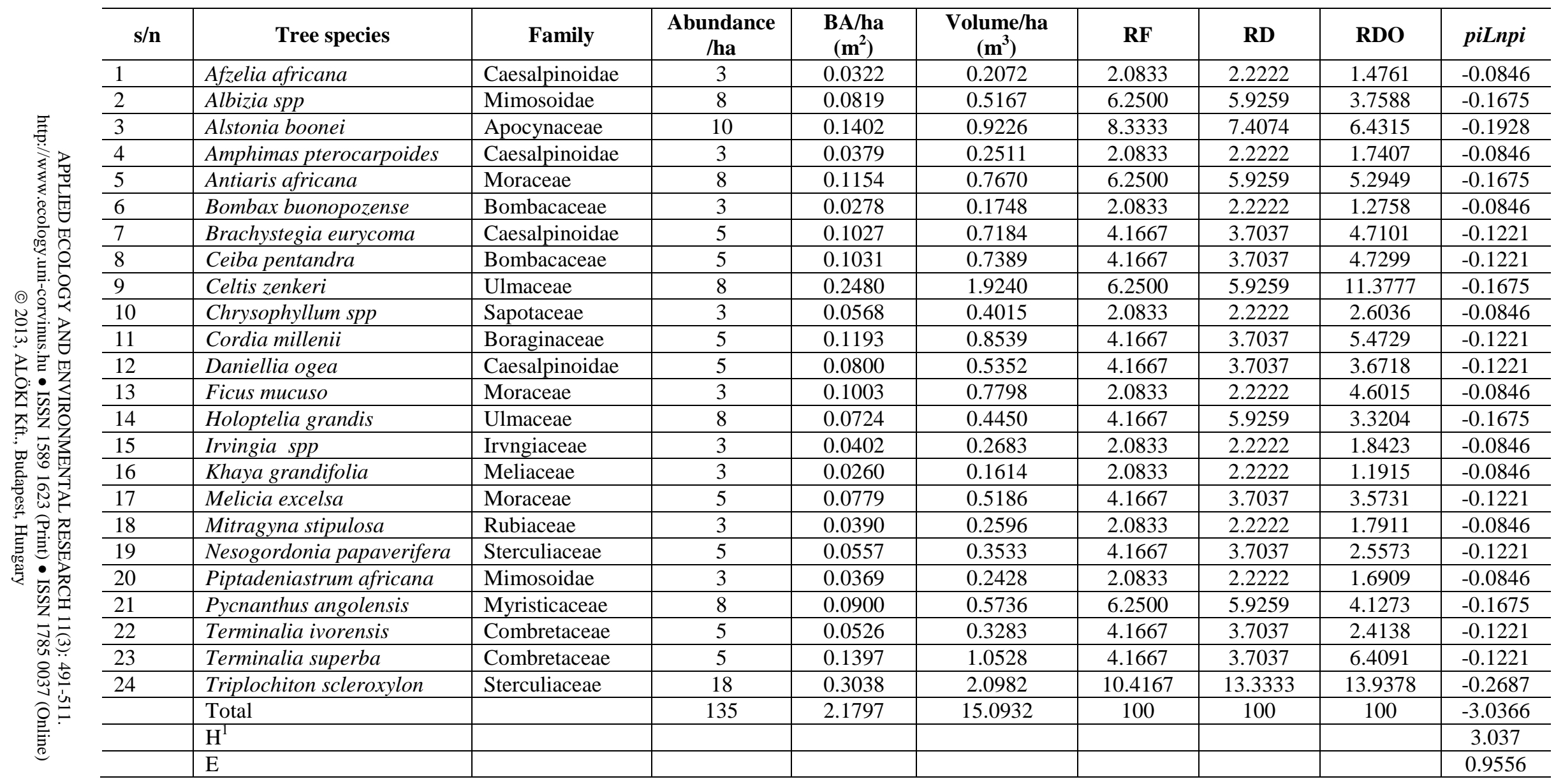




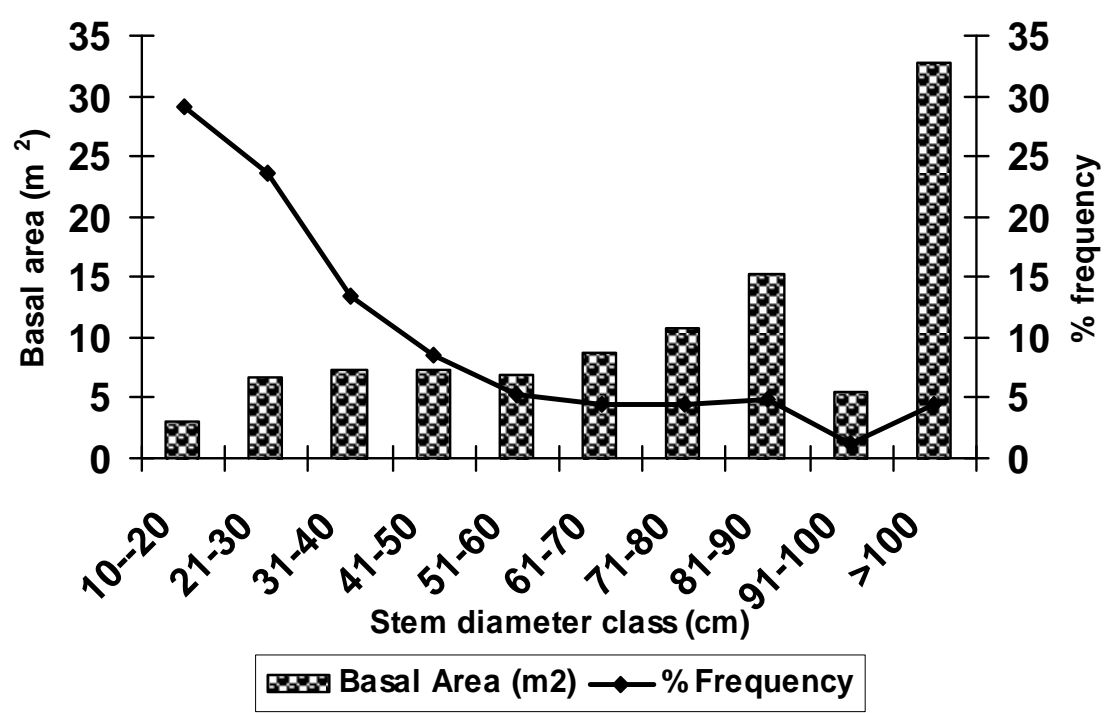

Figure 3. Distribution of number of stem/ha and basal area/ha into dbh classes for the inviolate site

\section{Tree Species diversity, structure and yield in the violate forest}

A total of 24 economic timber species distributed in 14 families were encountered in the violate part of this forest reserve (Table 3). The violate part is the rest portion of the forest where logging is allowed under the close supervision of the state forestry department. The Shannon-Wiener diversity index $\left(\mathrm{H}^{1}\right)$ was 3.037 and species evenness (E) was 0.96 . The forest association was dominated by Triplochiton scleroxylon (18 stems/ha), Alstonia boonei (10). Other co-dominant species are Albizia spp, Antiaris Africana, Celtis spp, Holoptelia grandis and Pycnanthus angolensis, each having 8 stems/ha. These together formed $29.17 \%$ f the forest association. Eight species, which accounted for $33.33 \%$, were represented by 5 stems/ha each; these include Brachystegia eurycoma, Ceiba pentandra, Cordia millenii, Daniellia ogea, Melicia excelsa, Nesogordonia papaverifera Terminalia ivorensis and Terminalia superba. Other species, having 3 stems/ha each, were categorized as the least abundant timber species in the forest reserve. These species are Afzelia africana, Amphimas pterocarpoides, Bombax buonopozense, Chrysophyllum spp, Ficus mucuso, Irvingia spp, Khaya grandifolia, Mitragyna stipulosa and Piptadeniastrum africana; they accounted for $37.5 \%$ of the total stems encountered in the forest. The correlation coefficients of the relationship between abundance and frequency, and abundance and dominance were 0.95 and 0.82 respectively.

The families Caesalpinoidae and Moraceae, with four and three species respectively, were the dominant families in this forest. Five families, namely, Bombacaceae, Combretaceae, Mimosoidae, Sterculiaceae and Ulmaceae have two species each. The rest seven families, which accounted for $50 \%$ of the total 14 families encountered, have only one species. This shows how logging has reduced tree species diversity and evenness.

Figure 4 shows the distribution of stem population per hectare and basal area per hectare into dbh classes in the selected area where active logging is going on. The stem diameter distribution of timber encountered ranged between $10 \mathrm{~cm}$ and $90 \mathrm{~cm}$. Forty- 
three percent of total stem/ha belongs to the least diameter class $(10-20 \mathrm{~cm})$. This is followed by $25 \%$ in $21-30 \mathrm{~cm}$ class. Only $7 \%$ of the trees are of merchantable size (i.e. $\mathrm{dbh}>40 \mathrm{~cm})$. This indicates that trees of merchantable size are very few in this forest site when compared with what was found in the inviolate area. A total basal area of 2.14 $\pm 0.12 \mathrm{~m}^{2} /$ ha was obtained and Triplochiton scleroxylon, which coincidentally is the most abundant species, contributed the highest basal area $\left(0.30 \mathrm{~m}^{2} / \mathrm{ha}\right)$, followed by Alstonia boonei and Cordia millenii (each with $0.12 \mathrm{~m}^{2} / \mathrm{ha}$ ). About $62.5 \%$ of the total timber species encountered in the forest has their basal area to be less than $0.10 \mathrm{~m}^{2} / \mathrm{ha}$. The pattern in volume/ha distribution for the timber species encountered in this site was similar to what was obtained for basal area/ha. The total volume/ha in this portion of Akure forest reserve where active logging is taking place summed up to $14.81 \pm 0.84$ $\mathrm{m}^{3} /$ ha. A strong correlation relationship of 0.995 also existed between basal area/ha and volume/ha (Table 4).

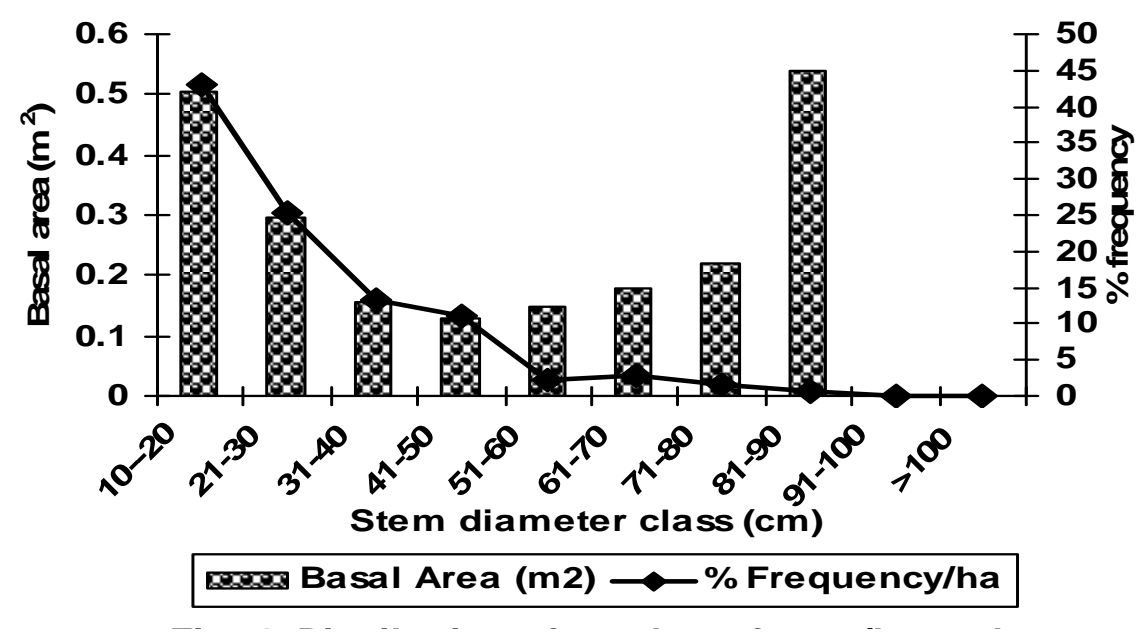

Figure 4. Distribution of number of stem/ha and basal area/ha into dbh classes for the inviolate forest

Out of the total 24 families of timber species encountered in both forest sites, eleven families $(45.83 \%)$ were common to the two sites; three $(12.5 \%)$ and ten $(41.7 \%)$ families were found exclusively in the violate and inviolate sections respectively. Generally, about $50 \%$ of the total families in this reserve were represented by only one species while $20.83 \%$ were represented by two species. The rest families $(29.17 \%)$ had three and above species. Caesalpinoidae, Sterculiaceae, Meliaceae and Moraceae were the dominant families. Table 5 gives the list of families and the corresponding number of species in the study areas. From this table, more species and families were exclusively present in the SNR than in the violate area. Species that were encountered in the SNR only were also more than the number of species that occurred repeatedly in both forest sites selected for this study. Even though the percentage of families in both sites was more than those found exclusively in the inviolate forest, but there was no significant difference $(\mathrm{p} \geq 0.05)$ in the values when they were compared with the student t-test. The result of the t-test also revealed a significant difference $(p \leq 0.05)$ in the number of species and families that were exclusively encountered in the SNR and 
the violate site. Figure 5 shows the total number of individual stem, number of species and number of families sampled in both the inviolate and violate plots.

The relationship between the area sampled and number of species encountered is presented in Figure 6. Continued sampling revealed additional taxa in both sites. Greater species richness of the inviolate forest is conspicuous and the trend was apparent even at small sample sizes. The slope of the two species-area curves did not approach zero. The correlation coefficients of the relationship between both forest sites in abundance, basal area, volume, frequency, density and dominance were $-0.12,0.05$, $0.02,-0.15,-0.12$ and 0.05 respectively. These correlation coefficients revealed a weak relationship between two sites in the same forest reserve. This has to do with the logging going on, on daily basis, in the violate area of the reserve.

Table 4. Correlation matrix for the selected violate site

\begin{tabular}{|c|c|c|c|c|c|c|}
\hline & Abundance/ha & $\begin{array}{c}\text { BA/ha } \\
\left(\mathbf{m}^{2}\right)\end{array}$ & $\begin{array}{c}\text { Volume/ha } \\
\left(\mathrm{m}^{3}\right)\end{array}$ & $\mathbf{R F}$ & RD & RDO \\
\hline Abundance/ha & 1 & & & & & \\
\hline BA/ha (m2) & 0.822103 & 1 & & & & \\
\hline $\begin{array}{l}\text { Volume/ha } \\
\text { (m3) }\end{array}$ & 0.764223 & 0.995029 & 1 & & & \\
\hline $\mathrm{RF}$ & 0.950618 & 0.809585 & 0.756033 & 1 & & \\
\hline RD & 1 & 0.822103 & 0.764223 & 0.950618 & 1 & \\
\hline RDO & 0.822103 & 1 & 0.995029 & 0.809585 & 0.822103 & 1 \\
\hline
\end{tabular}

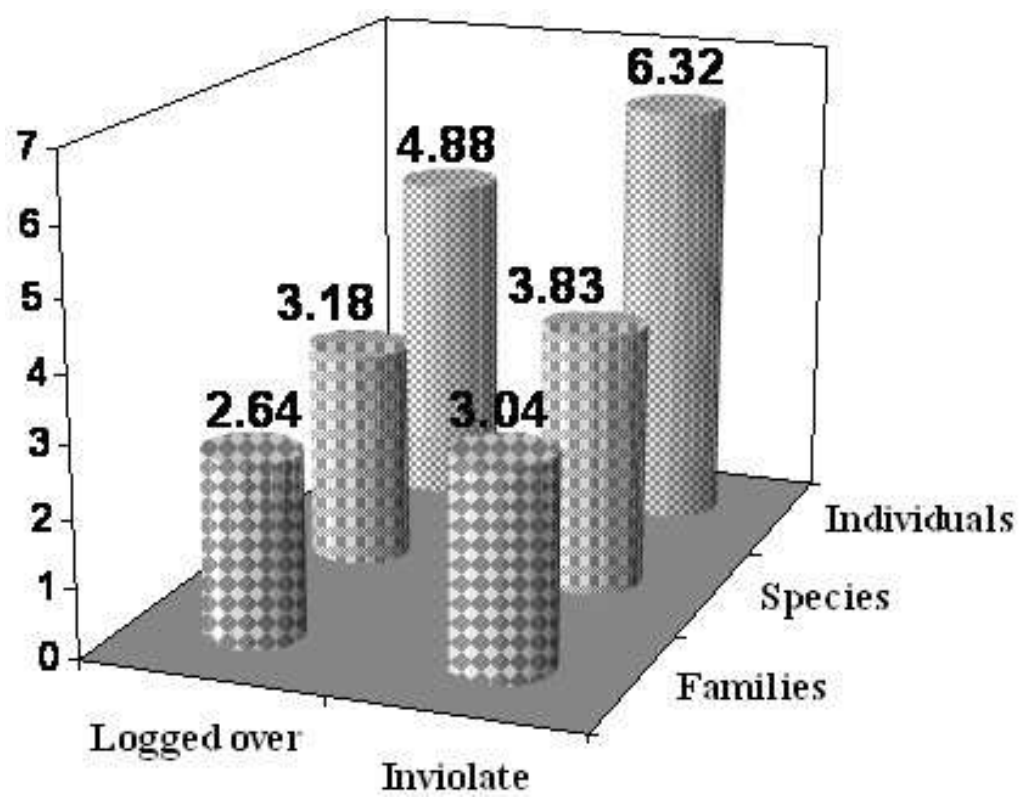

Figure 5. Total number of individuals, species and families in the selected violate and inviolate forests on a natural-log scale 


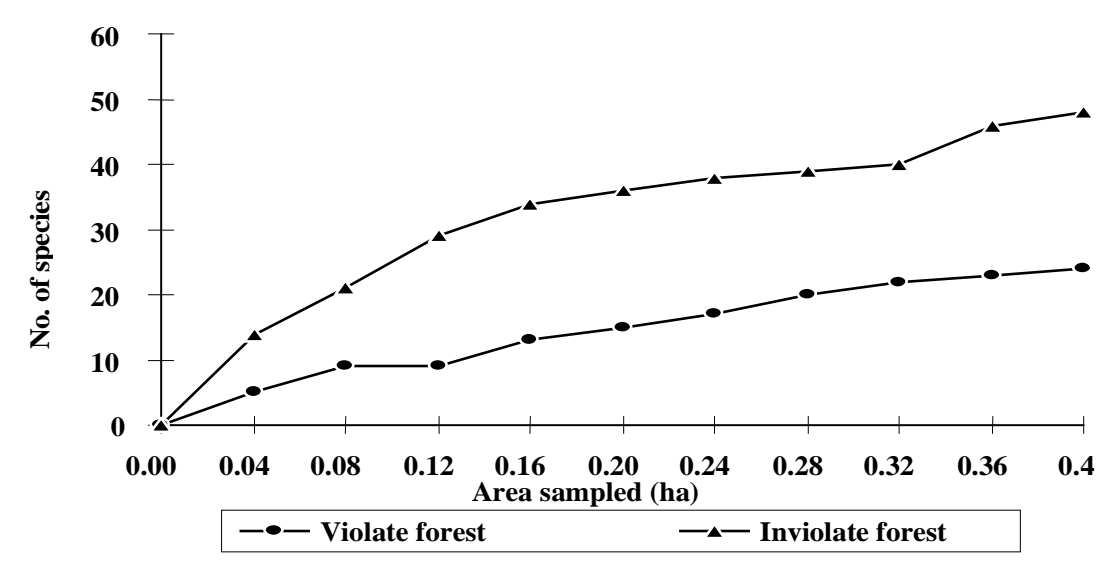

Figure 6. The relationship between tree diversity and sample area for timber species with $\geq 10 \mathrm{~cm}$ dbh in logged over and inviolate forests in the study area

\section{Comparison of tree species diversity and evenness in both forest types}

Tree species diversity indices, basal area and volume per hectare from both the inviolate (SNR) and the violate sections were pooled together to assess tree species diversity and evenness in the entire forest reserve. The result is presented in Table 6. While twenty four species were encountered in the logged over forest, forty six were present in the inviolate section. The result of Shannon-Weiner diversity index for inviolate forest (3.16) is higher than that of logged forest (3.04). Other tree growth variables obtained were higher for the inviolate when compared with those from the logged forest and there are significant differences in these values from the result of the student t-test. The result of the habitat occupancy and specialization for all the species and families is shown in figure 7. On the whole, a total of 54 timber species belonging to 24 families were encountered in this selected forest stands (Table 6). About thirty percent of these species were shared by both forest sites, $55.56 \%$ and $14.81 \%$ were found exclusively in the inviolate and logged over forest respectively. The sixteen species common to both sites are Cordia millenii, Afzelia africana, Berlinia confusa, Brachystegia eurycoma, Terminalia superba, Khaya grandifolia, Piptadeniastrum africana, Antiaris africana, Ficus spp, Melicia excelsa, Mitragyna stipulosa, Chrysophyllum spp, Nesogordonia papaverifera, Triplochiton scleroxylon and Celtis spp. These are referred to as habitat generalists (Adekunle, 2005). The Shannon-wiener diversity index for the timber resources when the species encountered from both forest sites were pooled is 3.38 and the corresponding overall species evenness is 0.85 . 


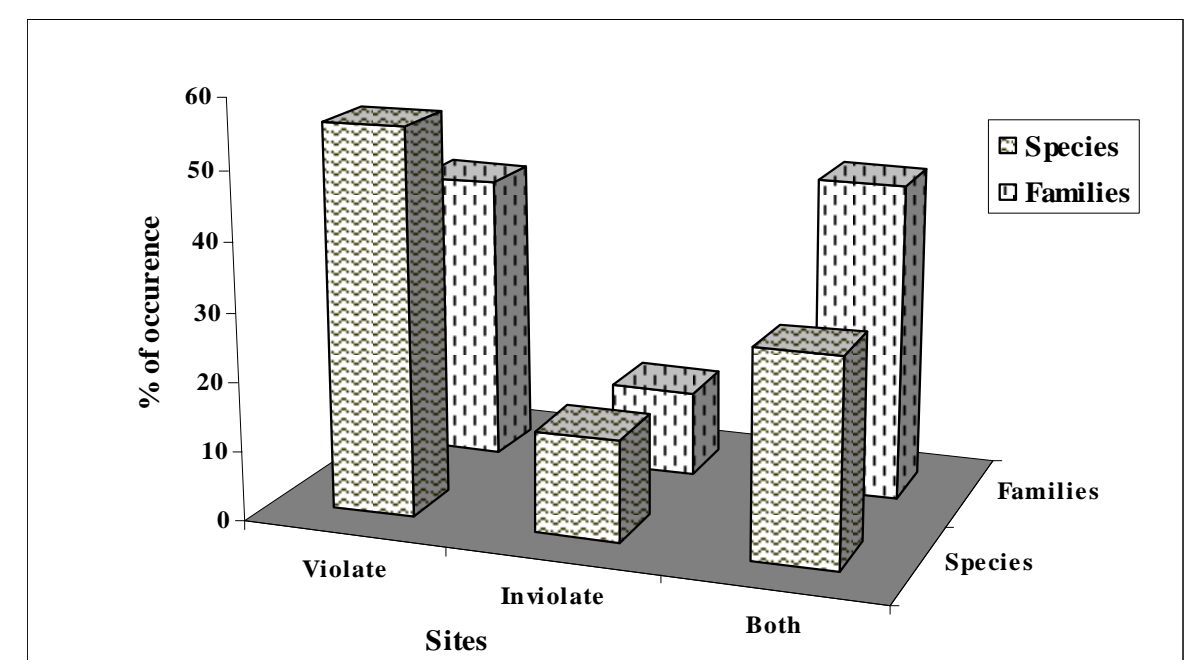

Figure 7. Habitat Occupancy of species and families in Akure forest reserve

Table 5. Family distribution of species in the studied forests

\begin{tabular}{l|l|c|c}
\hline \multirow{2}{*}{$\mathbf{s} / \mathbf{n}$} & \multicolumn{1}{|c|}{ Family } & \multicolumn{2}{|c}{ No. of species } \\
\cline { 3 - 4 } & & Violate forest & Inviolate forest \\
\hline 1 & Anacardiaceae & - & 1 \\
2 & Annonaceae & - & 1 \\
3 & Apocynaceae & 1 & 1 \\
4 & Bombacaceae & 2 & - \\
5 & Boraginaceae & 1 & 1 \\
6 & Caesalpinoidae & 4 & 6 \\
7 & Combretaceae & 2 & 2 \\
8 & Ebenaceae & - & 1 \\
9 & Euphorbiaceae & - & 3 \\
10 & Irvngiaceae & 1 & - \\
11 & Lecythidaceae & - & 1 \\
12 & Meliaceae & 1 & 5 \\
13 & Mimosoidae & 2 & 1 \\
14 & Moraceae & 3 & 5 \\
15 & Myristicaceae & 1 & - \\
16 & Ochnaceae & - & 1 \\
17 & Papilionoidae & - & 3 \\
18 & Rubiaceae & 1 & 3 \\
19 & Rutaceae & - & 1 \\
20 & Sapindaceae & - & 1 \\
21 & Sapotaceae & 1 & 1 \\
22 & Simaroubaceae & - & 1 \\
23 & Sterculiaceae & 2 & 6 \\
24 & Ulmaceae & 2 & 1 \\
& Total & 24 & 46 \\
\hline
\end{tabular}


Table 6. Summary of tree species diversity variables in the study areas

\begin{tabular}{l|c|c|c}
\hline \multirow{2}{*}{\multicolumn{1}{c|}{ Variable }} & \multicolumn{2}{|c|}{ Forest Type } & \multirow{2}{*}{ Both sites } \\
\cline { 2 - 3 } & Violate & Inviolate & \\
\hline Species richness & 24 & 46 & 54 \\
No. of Families & 14 & 21 & 24 \\
Shannon diversity index & 3.037 & 3.162 & 3.38 \\
Species evenness & 0.96 & 0.83 & 0.85 \\
Stem density (stems/ha) & $132.5 \pm 7.5$ & $555 \pm 63.33$ & 684 \\
Mean tree dbh (cm) & $14.24 \pm 0.75$ & $39.35 \pm 3.14$ & 26.80 \\
Dominant dbh (cm) & 30 & 210 & 210 \\
Basal area/ha $\left(\mathrm{m}^{2}\right)$ & $2.18 \pm 0.12$ & $104.19 \pm 12.02$ & 106.37 \\
Volume/ha $\left(\mathrm{m}^{3}\right)$ & $15.09 \pm 0.84$ & $1221.67 \pm 140.94$ & 1236.76 \\
\hline
\end{tabular}

\section{Discussion}

Adekunle (2006) noted that the number of tree species is far greater in the tropical rainforest than in any other single forest community regardless of plot size. The 46 species in 24 families encountered in the inviolate forest are tropical timber hardwood species dominating the tropical rainforest ecosystem. They are of high economic values to rural livelihood and nation development. Only 21 of such species in 14 families were present in other portion of the reserve where logging has been allowed. The species absent from the logged over forest but present in the unlogged forest are essentially tree species that of high market demand. These species are usually identified in the reserve and cut by loggers without any regard to their sizes and prevailing logging policies. However, timber species richness of 54 recorded in this study compared favourable with what had been recorded for other similar ecosystem in southern Nigeria. For instance, 68 species were recorded in the Cross River state Nigeria by Abayomi (2001) while Ojo (2004) obtained 71 species for Abeku sector of Omo forest reserve in 2000.

Several researchers have adopted the use of Shannon-Weiner diversity index to investigate ecosystem diversity as it takes into consideration both the species richness and evenness in a community (Onyekwelu et al., 2005). The overall diversity index (Shannon-Weiner diversity $\left(\mathrm{H}^{1}\right)$ ) of 3.04 for logged forest, 3.16 for inviolate forest and 3.38 obtained when the species encountered from both sites were pooled is very close to the range of values (3.34-3.66) reported for some tropical rainforest sites in southern Nigeria by Adekunle (2006) and Adekunle and Olagoke (2007). This result is an indication that biological diversity is adequately conserved through the establishment of SNR especially for native species, keystone species and species with narrow range. The sacred groves were means of biodiversity conversation in the past. These are patches of forest land where human interference is completely prohibited with local laws and taboos. But the advent of civilization and modern religion has made encroachment into majority of these groves to be possible. Therefore the only hope for insitu conservation today is the effective management of strict nature reserves.

Regardless of how long trees were clear-cut or selectively removed, logging decreased species diversity (Brown and Gurevitch, 2004) and the number of economic trees. Thus, from the results of Shannon-Weiner diversity index $\left(\mathrm{H}^{1}\right)$, inviolate forest was more biologically diverse than the logged over forest, though there was a considerable similarity in the $\mathrm{H}^{1}$ values of the two forests. Similar trends have been 
observed in other tropical rainforest ecosystem (Brown and Gurevitch, 2004; Makana and Thomas, 2006). These researchers established the fact that logging affects tree species diversity and evenness. Meanwhile, a higher species evenness in the logged over forest showed that timber species are slightly more evenly distributed in the logged over forests than in the inviolate forest. This could be attributed to canopy opening created when big trees are cut in the logged forest area.

Logging appears to be the overriding force driving plant invasion, and plant invasion is a major predictor of reduced native species diversity (Brown and Gurevitch, 2004). It was observed that the representatives of Bombacaceae, Irvingiaceae and Myristicaceae which were not encountered in the inviolate forest had gained much prominence in the logged over forest, though it was difficult to establish whether those species have the ability to invade the closed-canopy of the inviolate unlogged forest. Meanwhile, the absence of representative of Anacardiaceae, Annonaceae, Ebenaceae, Euphorbiaceae, Lecythidaceae, Ochnaceae, Papilionoidae, Rutaceae, Sapindacea and Simaroubaceae could be an indication for the loss of such species in the logged over forest area as consequent to timber exploitation. These families were represented in the inviolate forest by few numbers of species. So, urgent conservation measure is recommended for the forest reserve.

There were significant differences when tree species diversity indices and tree growth variable (number of stem, basal area and volume per hectare) obtained from the violate and inviolate plots were compared with the student t- test with values from the inviolate forest ranking higher. Onyekwelu et al. (2005) has attributed a higher basal area and standing volume productivity in Queen Forest to effect of conservation, bearing in mind that the forest has not been exploited within living memory. The higher stem density, basal area and standing volume productivity in the inviolate forest can also be attributed to similar reasons. The reduction in the number of stems and volume of timber species as a result of over-exploitation and loss of some of the species from the logged over forest has placed such species on the list of endangered species in Ondo state. Similar observation was made and reported for Ekiti state (Falaye et al., 2006). The mean basal area and dbh of where logging is in active progress is less than the stipulated value recommended for any forest reserve where logging should be allowed. So, further logging is not advisable in this forest any longer. The small diameter tree should be left to mature.

Threatened and endangered species, according to Formecu (1999) that were identified in the course of this study include Terminalia superba, Triplochiton scleroxylon, Afzelia africana, Sterculia rhinopetala, Mansonia altissima, Cordia millenii, Melicia excelsa, Nesogordonia papaverifera, Antiaris africana, Dialium spp, Pterygota macrocarpa, Khaya spp, Alstonia boonei and Brachystegia eurycoma. Most of these species were encountered on once in the study sites. Apart from the impacts of logging on tree species diversity, the resultant effect of logging on the environment is great. According to Fuwape (2001) forest exploitations are not well planned and executed in Nigeria, so it is deleterious to the environment.

\section{Conclusion and recommendation}

This study has established that continuous forest exploitation could lead to the loss of biodiversity and reduction in tree yields. The study has also revealed the present status of Akure forest reserve in totality, the SNR and the logged portion in particular. The 
role of forest ecosystem in environmental conservation cannot be overestimated. Tree removal has severe impact on environment. Species and families now encountered in the inviolate forest only were also present in other part of the forest before. But they have been removed from the area where logging has taken because of their economic importance. It is therefore recommended that this SNR should be given proper attention to prevent encroachment by desperate timber loggers. Logging should not be allowed in this reserve again. It should be left alone to recover from its present situation. Some of the degraded forest reserves in Nigeria should be constituted as strict nature reserves to prevent biodiversity loss and protect the environment.

\section{REFERENCES}

[1] Abayomi, J.O. (2001): A Timber Resources Assessment of some Natural Forest Sample Plots in Cross River State, Nigeria. - 2001 Conference Proceedings of Forestry Association of Nigeria. pp 17-26.

[2] Adekunle, V.A.J. (2005): Trends in Forest Reservation and Biodiversity Conservation in Nigeria. - In: Environmental Sustainability and Conservation in Nigeria, Okoko, E., Adekunle, V.A.J. \&Adeduntan, S.A. (editors) Environmental Conservation and research Team, Federal University of Technology, Akure Nigeria, pp 82-90.

[3] Adekunle, V.A.J. (2006): Conservation of tree species diversity in tropical rainforest ecosystem of southwest Nigeria. - Journal of Tropical Forest Science 18(2): 91-101.

[4] Adekunle, V.A.J., Olagoke, A.O. (2007): Diversity and biovolume of tree species in natural forest ecosystem in the bitumen-producing area of ondo state, Nigeria: a baseline study. - Biodiversity and Conservation: DOI 10.1007/s10531-007-9279-y.

[5] Adeola, M.O.: Present and potential sources of water pollution: effects on wildlife and resources. - In: Aina, E.O.A., Adedire, N.O. (editors) Federal Environmental Protection Agency Monograph 2 pp 295-302.

[6] Alfred, S.D.Y. (2005): Sustainable Environment: Application of psycho-motivational theories. - In: Environmental Sustainability and Conservation in Nigeria, Okoko, E., Adekunle, V.A.J., Adeduntan, S.A. (editors) Environmental Conservation and research Team, Federal University of Technology, Akure Nigeria pp 2-4.

[7] Bibalani, G.H., Golshani, A.A., Najafian, K.A. (2006): The traction effect of lateral roots of gavan (Astragahus raddei) on soil reinforcement in Northwest Iran. - Canadian Journal of Soil Science 86: 493-499.

[8] Bibalani, G.H., Majnounian, B. (2007): Protection roles of tea scrubs (Thea sinensis, L.) on slopes in Iran. - Research Journa of Environmental Sciences 1(4): 159-165.

[9] Brashears, M.B., Fajvan, M.A., Schuler, T.M. (2004): An Assessment of Canopy Stratification and Tree Species Diversity Following Clearcutting in Appalachian Hardwoods. - Forest Science 50(1): 54-61.

[10] Brown, K.A., Gurevitch, J. (2004): Long-term Impacts of Logging on Forest Diversity in Madagascar. - PNAS 2004 101(16): 6045-6049.

[11] Falaye, T.A., Oluyege, A.O., Olufemi, B., Fuwape, J.A. (2006): Timber Exploitation Pattern in the Forests of Ekiti State, Nigeria from 1996-2001. - In: Agricultural Research for Development in Nigeria, Onibi, G.E., Agele S.O. Adekunle V.A.J., Akinbulumo, M.O. (editors) Proceedings of the of $2^{\text {nd }}$ Annual Conference of School of Agriculture and Agricultural Technology, Federal University of Technology, Akure, Nigeria, $24^{\text {th }}$ May, 2006. pp 87-93.

[12] FAO (1990): Forest resources assessment 1990: Tropical counties. - Food and Agricultural Organization Forestry Paper 112, Rome, Italy

[13] FORMECU (1999): Forest Resources Study, Nigeria. - Revised national report Vol. 2. Prepared for FORMECU by Beak and Geomatics international, pp. 224. 
[14] Fuwape, J.A. (2001): The Impacts of Forest Industries and Wood Utilization on the Environment. - ODSG-FAN CONSULT Workshop on Forest industries, Environment and Sustainable Development. JTFR 17(2): 78-90.

[15] Gbile, Z.O. (1984): Vernacular Names of Nigerian Plants-Yoruba. - Forestry Research Institute of Nigeria, Ibadan, Nigeria.

[16] Ikhuoria, I.A., Ero, I.I., Ikhuoria, A.E. (2006): Satellite detection and GIS analysis of Lowland rainforest reserve reduction in Edo state, Nigeria. - In: Imperatives of space technology for sustainable forest management. Salami, A.T. (ed.) Proceedings of an international stakeholders' workshop sponsored by National Space Research and Development Agency held In Abuja, Nigeria between 27 and 28 March 2006. p. 72-93.

[17] Isichei, A.O. (1995): Omo biosphere reserve, current status, utilization of biological resources and sustainable management (Nigeria). - Working Paper No. 11, 1995 UNESCO (South South Cooperation Programme) Paris, France pp. 48.

[18] Keay, R.W.J. (1989): Trees of Nigeria. - A revised version of "Nigeria Trees" (Keay, et al., 1964) Clarendron Press, Oxford. pp. 476.

[19] Laurance, W.F. (2001): Tropical logging and human invasions. - Conservation Biology 15: 4-5.

[20] Lynch, A.K., Jones, E.T., Mclain, R.J. (2004): NTFP inventorying and monitoring in the USA: rationale and recommendations for a participating approach. - Report Submitted to the National Commission on Science for Sustainable Forestry. www.ifcae.org.

[21] Mabogunje, A.L. (1988): The debt to postperity: Reflections on a National policy on environmental management: - In: Sada, P.O., Odemerho, F.O. (editors). Environmental issues and management in Nigerian Development, pp. 17-25.

[22] Makana, J., Thomas, S.C. (2006): Impacts of Selective Logging and Agricultural Clearing on Forest Structure, Floristic Composition and Diversity and Timber Tree Regeneration in the Ituri Forest, Democratic Republic of Congo. - Biodiversity and Conservation 15: 1375-1397.

[23] Oduwaiye, E.A., Oyeleye, B., Oguntala, A.B. (2002): Species Diversity and Potentiality for Regeneration in Okomu Permanent Sample Plot. - In: Forestry and Challenges Of Sustainable Livelihood, Abu, J.E., Oni, P.I., Popoola, L. (eds) Proceeding of the $28^{\text {th }}$ Annual Conference of the Forestry Association of Nigeria, Akure, Nigeria. $4^{\text {th }}-8^{\text {th }}$ Nov. 2002, pp. 264-271.

[24] Onyekwelu, J.C., Adekunle, V.A.J., Adeduntan, S.A. (2005): Does Tropical Rainforest Ecosystem Possess the Ability to Recover from Severe Degradation? - In: Sustainable Forest Management In Nigeria: Lessons and Prospects. Popoola, L., Mfon, P., Oni, P.I. (eds) Proceeding of the $30^{\text {th }}$ Annual Conference of the Forestry Association of Nigeria, Kaduna, Nigeria. $07^{\text {th }}-11^{\text {th }}$ Nov. 2005, pp. 145-163.

[25] Pascal, J.P., Pelissier, R. (1996): Structure and floristic composition of a tropical evergreen forest in south-west India. - Jr. Trop. Ecol. 12: 191-214.

[26] Price, P.W. (1997): Insect ecology. $-3^{\text {rd }}$ Edition, Wiley, NY.

[27] Putz, F.E., Kent, H.R., John, G.R., Robert, F., Geoffrey, M.B. (2000): Biodiversity Conservation in the context of tropical forest management. - Biodiversity Series - Impact Studies Paper No. 75, Washington D.C.

[28] Ranasingbe, D.M., Abayasari, S. (2007): Forestry Education and global change: a case study on the contribution of forest plantation in Sri Lanka as an adaptation measure to climate change. - In: Improving forestry education. Temu, A. (ed.) Proceeding of First Global Workshop on improving Forestry Education in Africa Under the auspices of International Partnership on Forestry Education, at ICRAF Campus, Nairobi, Kenya, 2527 September 2007. pp. 16-22.

[29] Reiss, S., Roliter, L., Jensen, H., Came, B., Talor, J., Lord, M. (1980): "Vanishing Forest" - Topic 34: 39-43.

[30] Salami, A.T. (2006): Monitoring Nigerian forest with Nigeria Sat-1 and other satellites. In: Imperatives of space technology for sustainable forest management. Ayobami, T.S. 
(ed.) Proceedings of an international stakeholders' workshop sponsored by National Space Research and Development Agency held In Abuja, Nigeria between 27-28. March 2006., pp. 26-61.

[31] Secretariat of the Convention on Biological Diversity (SCBD) (2001): Sustainable management of NFTP resources. - Montreal, CBD Technical Series 6.

[32] SPSS (2003): Statistical package for social sciences, 14.0 for windows. - SPSS Inc. Illinios, USA.

[33] Verchot, L. (2007): A look at the horizon at climatic change issues relative to forestry: Opportunities for relevant forestry research toward 2030. - In: Improving forestry education. Temu, A. (ed.) Proceeding of First Global Workshop on improving Forestry Education in Africa Under the auspices of International Partnership on Forestry Education, at ICRAF Campus, Nairobi, Kenya, 25 - 27 September 2007, pp. 1-15.

[34] Walther, G.R., Post, E., Convey, P., Menzel, A., Parmesan, C., Beebee, T.J.C., Fromentin, J.M., Hoegh-Guldberg, O., Bairlein, F. (2002): Ecological responses to recent climate change - Nature 416: 389-395.

[35] Wilkie, D.S., Shaw E., Rotberg, F., Morelli, G., Auzel, P. (2000): Roads, development, and conservation in the Congo basin. - Conservation Biology 14: 1614-1622.

[36] World Bank (1991): Forest Sector Policy Paper. - The World Bank, Washington, D.C., USA.

[37] Wu, T.H., Mckinnell, W.P., Swanston, D.N. (1979): Strength of tree roots and landslides on Prince of Wales Island, Alaska. - Canadian Geotech. Journal 114: 19-33. 